\title{
Economic Development or Environmental Protection? The Dilemmas of the Developing Countries through the Case of the Philippines
}

\author{
By Péter Klemensits
}

\begin{abstract}
As the term sustainable development has become more important to the world, in the developing countries it means a serious conflict of interest considering the conservation of the environment versus the economic development. For the states of the Global South it is a near-impossible challenge to create a responsible environmental policy and at the same time secure the long-term development of their economies and societies. The case of the Philippines can be cited as an ideal example, as under the presidency of Rodrigo Duterte the government is struggling to reconcile the opposing interests, while the environmental degradation seems to be incontrollable.

The present paper examines the challenges confronted by the developing countries in Africa, Asia and Latin America through the case study of the Philippines. The analysis based on the literature presents in detail the country's ecological crisis, President Duterte's environmental policy, and the long term socioeconomic prospects alike. The paper concludes that in favour of the sustainable development the environmental protection can no longer be put into the shade by sheer economic interest, even if the challenge became more difficult for the elites in the future.
\end{abstract}

Keywords: sustainable development, economic policy, environment protection, Philippines, Global South

\section{Introduction}

While the developed countries have already become committed towards the provision of sustainable development, in the states of the global South the compatibility of economic development and environmental protection is a serious issue. In numerous African countries the political and economic conditions do not allow for the pursuance of a responsible environmental policy, but even in the more highly-developed Latin American and Asian regions - where the political, economic and social conditions are more beneficial - there is a serious conflict of interests between the political ambitions aiming at long-term economic and social development and the preservation of the environment for the future generations. This kind of ambivalence can be clearly seen on the Philippines, where - after President Rodrigo Duterte's inauguration in 2016 - the Government made considerable efforts for environmental protection, while they also treated economic development as a high priority (Manahan, 2017). The mitigation of the contradictory interests, however, means a greater and greater challenge, while the damaging of the environment threatens with severe consequences.

The author aims to present all such issues through the model of the Philippines that affect most of the developing countries during the reconcilement of environmental 
protection and economic policy. Apart from the different geographical, economic and social endowments of the states, in numerous countries the political leadership is not committed towards the double aims similar to the Duterte Government; nevertheless, the success or the failure of the Philippine reforms can serve as a severe lesson concerning the future.

\section{The right to development}

The objective judgement of the policy of the developing countries leaves much to be desired regarding the developed North, which - besides the internal factors influences the economic and environmental facilities of the global economies of the South from the outside, too. The protection of the environment is a joint responsibility, which the developing countries should also take a hand with. Nevertheless, they also have the right to development, which means that they have the right to set out on the way that the states of the developed North have already finished. The main point is that any country can need sustainable development; however, this assumes some limited economic development, in close harmony with environmental protection. In this approach, development means not only economic prosperity but also human development, that is, it also includes broader enforcement of human rights and the democratic values (Ngosso, 2013). In the countries of the Global South the political systems decrease the importance of this latter factor, while the reigning elite primarily focuses on the economic development.

As a result of globalization, the exploitation of raw materials has come to the front for the establishment of international competitiveness, while industrialization also continues, enhancing the damaging of the environment (Esty and Ivanova, 2004). The negative consequences of the process can only be supported with the active support of the developed countries, but no consensus have been realized even about the real environmental purposes. A progress is that, to observe the agreements concluded during the Paris Climate Summit in 2015, the developing countries also assumed commitments - challenging though the real intentions of the West - although the resignation of the United States of America in 2017 definitely affected the process adversely, highlighting again the differences between the developing and the developed countries (Plumer, 2017). On the other hand, the absence of the US offers a unique opportunity to developing countries such as China or India, who have become the front-line fighters against the West against climate change but are unable to surrender economic development, too.

\section{Case study: the Philippines}

With its over 100 million inhabitants, the Philippines has the 34st largest economy in the world and basically belongs to the group of the newly industrialized, emerging nations. Today Asia is considered one of the most rapidly growing economies; in 2017 the country produced a GDP growth of 6.7\% (Tubayan, 2018). As a result of the enormous property inequalities, however, $21.6 \%$ of the population lived below the property threshold in 2015 (ADB, 2018). In 2017, the unemployment rated 5.7\% besides 
the 2.9 inflation, which is an especially serious issue in the regions stricken with political, social and religious conflicts (e.g. Mindanao) (Focus Economics, 2018; Altez and Caday, 2017). Besides agricultural and industrial products, the main export articles include raw materials. The greatest challenge for the Government is the different developmental levels of the regions, the unsolved social conflicts, corruption and poor infrastructure (Batalla, 2018).

Unlike numerous African and Latin American countries, the Philippines seems to be in an advantageous position in terms of its development; however, economic development resulted in such extent of environmental damage that cannot be ignored by the Government in the future. In the lack of appropriate industrial sewage cleaning, 58\% of the subsoil water is contaminated, and $75 \%$ of the river-waters is unsuitable for human consumption (Marrone, 2016). Flowing into the Manila Bay, the River Marilao is one of the 10 most polluted rivers in the world. As a result of uncontrollable deforestation and illegal wood cutting, the forest cover decreased from $70 \%$ to $20 \%$ during the $20^{\text {th }}$ century (that is, to 1.3 million hectares) (Lasco et al. 2001). Consequently, landslides cause more and more issues. Although to a different extent, air pollution affects $98 \%$ of the population, causing the death of every fourth person annually (DENR, 2017). The situation is the worst mainly in Manila and other cities due to the constant smug. As a result of the environment-damaging activity and the global warming, the country has become more exposed to natural disasters as well. In 2013 the Yolanda Typhoon caused the death of at least 6,000 people in the Philippines (Rappler, 2017).

Over the past 30 years, the current Philippine Government has numerously expressed its commitment towards environmental protection; however, little progress has actually been made because the economic interests have surpassed the ecological interests in most cases. The issue of environmental protection was already included in the currently valid constitution that became effective in 1987. Drafted in 1991, the Philippine Strategy for Sustainable Development served as the basis for the Philippine Agenda 21, the draft on sustainable development. Manila also supported the United Nations Framework Convention on Climate Change signed in Rio de Janeiro in 1992, or the Kyoto Protocol ratified in 2003 (PCW, 2018). Later the Clean Development Mechanism was also adopted, supplemented with the commitments laid down in the Kyoto. Besides the presidential decrees and acts, the National Framework Strategy on Climate Change 20102022, drafted in 2010, also worth mentioning as a document taking a stand for the preservation of natural ecosystems and the provision of sustainable development (CCC, 2013).

\section{President Duterte's agenda}

By the 2010s it had become clear that the one-sided enforcement of economic interests has created a situation in the country that threatens with an ecological disaster in numerous areas. However, the ignorance of environmental protection will exert a negative influence on the economic development, too; nevertheless, the Benigno Aquino Government, being in office between 2010 and 2016, failed to find an efficient solution to the problem. Illegal wood cutting and the spread of mining and coal-fired power 
stations both contributed to the pollution of the air, waters and soil and jeopardized the subsistence of several millions of people, let alone the inducement of natural disasters.

Earlier President Rodrigo Duterte as Mayor of Davao banned mining in the territories under the jurisdiction of the municipality, and in his president election campaign he also demanded the representatives of the sector to entirely comply with the environmental requirements. After his election his Presidency promised significant reforms for the first 100 days. He held out the prospect of the supervision of mining permits, the banning of establishing new mines, ruthless fight against illegal wood cutting and fishing, the reassessment of the energy supply of the country, the introduction of a moratorium against new coal-fired power stations, and the gradual conversion to renewable energy sources (Manahan, 2017). Overall, Duterte promised to take 60 reform actions in 9 subfields, from responsible mining through fight against climate change, until responsible waste management, which were unanimously supported by the environmental organizations.

\section{Duterte's socio-economic policy}

Duterte's environmental program cannot be separated from the President's economic and social reforms aiming to enhance the development of the country. The economic policy of the Duterte Government, which has been given the name DuterteNomics, primarily aims to make the country one of the high-middle-income economies by 2020. Officially launched in April 2017, DuterteNomics includes all the economic and social political ideas released by the President as Ten-point agenda in June 2016. Among others, this 10-point program stood up for continuing the macroeconomic policy of the earlier Administration, promised a large-scale tax reform, the increasing of competitiveness, the improvement of the rural areas, healthcare and education as well as the promotion of investments (PCOO, 2017; Miller, 2018). The mid-term plan adopted in 2017 includes the above objectives in their entirety. Based on the opinion of the Filipino citizens, the 25-year long-term vision called Ambisyon Natin 2040 also deems the coordination of economic-social programs and developments as the main objective, and it also attaches great importance to education, because the aim is to establish a prospering "smart and innovative" middle class by 2040 (Update Philippines, 2016).

Nevertheless, the key aspect of DuterteNomics is the Build! Build! Build! Infrastructure Plan, which intends to decrease poverty and promote economic growth and social welfare through infrastructure investments covering the whole country. A considerable part of the scheduled projects facilitates the development of transport and would primarily be realized from state funding. During the 6 years of his office, Duterte plans to devote USD 180 billion to infrastructure developments and raise a part of the costs from foreign sources. In the autumn of 2017 the President approved the launch of 21 projects to the value of USD 16 billion (Reuters, 2017).

Based on the above, the Philippine Development Plan (PDP) 2017-2022 was drafted in 2017 , with the primary aim of decreasing the proportion of people living in property to $14 \%$ by 2022 . Also, besides infrastructure development, he also lays great emphasis on the maintenance of the ecological balance and the creation of a clean and healthy environment. As part of this, the conversion to renewable energy sources, the 
rehabilitation after natural disasters, the establishment of infrastructure resisting the climate change and the supporting of endangered communities are new elements (NEDA, 2017).

\section{Clash of interests}

Duterte's plans on environmental protection and economic policy seem to complement each other; however, the clash of opposite interests soon became evident, mainly affecting the mining sector. In June 2016 the President appointed Regina Lopez as head of the Philippine Department of Environment and Natural Resources (DENR), who gained reputation as a dedicated environmentalist and activist and whose initiatives compelled the support of the population, too. Lopez was considered a sworn enemy of open mining and was ready to relentlessly act against mining corporations, keeping the President's promise. Accordingly, she ordered the supervision of all mining activities and announced a moratorium on the new mines (Shneider, 2017). Due to the violation of environmental requirements, the Ministry decided in the closure of 23 mining operations, suspension of 5 contracts and the termination of 75 mineral production sharing agreements, affecting 70\% of the metal mines (Manahan, 2017). Although mining comprises only $3 \%$ of the Philippine export, the Philippines is considered one of the largest nickel and copper exploiters in the world, and the political influence of the sector is determinative.

In the beginning, Duterte favoured Lopez; however, he searched for a compromise after most government members, headed by Minister of Finance Carlos Dominguez, qualified the action as detrimental to the environment. After the Senate Commission on Appointments failed to approve of Lopez's ministerial appointment in May 2017, the President accepted the decision and appointed Roy Cimatu retired General and former Chief of Staff of the Armed Forces of the Philippines as his successor, who was an acceptable person for the mining lobby, too (Santos, 2017). His duty was to find a compromise between the environmentalists and the mining groups. The interpenetration of the economy and policy and the presence of corruption are certified by Duterte's statement to Lopez: „But you know how it is. This is democracy. And lobby money talks" (Ranada, 2017). In November 2017 the Mining Industry Coordinating Council already proposed the retraction of the order on banning the opening of new mines, which was supported by the Minister, too; however, Duterte refused to do so. In April 2018 the President still held out the prospect of prolonging the moratorium until 2019; but on the other side the enforcement of the earlier decisions concerning the operating mines was not materialized. Finally, in July 2018 the DENR lifted the moratorium on exploration permits for minerals, at the same time it found that 23 of the 27 suspended mining sites are compliant with the regulations therefore only 4 could face closure in the future (Dela Cruz, 2018; Palatino, 2018). Although not all of actions by Lopez have officially been retracted, the economic interests have gained a victory over environmental considerations, and the radical reforms had no chance of success (Ranada, 2018). 


\section{The administration's balancing policy}

With the appointment of Regina Lopez the President demonstrated that he does not shrink for his aims from brave and radical steps; however, his contradictory statements have already suggested that he is forced to make compromises in the interests of economic development, although he also takes environmental protection seriously. Actually, the Head of State considers the maintenance of ecological integrity and the protection of natural values as aspects of key importance for the realization of the economic and social development, and he only disagrees with their excessive and unlimited exploitation (Manahan, 2017). This is well illustrated by the National Greening Program, under which the Government would like to implement the plantation of forests in an area of 1.2 million hectares between 2017 and 2022 in the interests of sustainable sylviculture (DENR, 2018).

While Regina Lopez aimed at the use of renewable energy sources in $100 \%$, which was favoured by the governmental measures, too, Duterte explained several times that coal is still the cheapest energy source for the industrialization of the country, so he permitted the construction of new power stations (Jerusalem, 2016). He also held out the prospect of rehabilitating the only nuclear station of the country that was built but never commissioned (Lucas, 2016).

Earlier the President criticized the Paris Clime Treaty, which he did not intend to sign, but in February 2017 he did so (Salaverria, 2017). Similarly to the leaders of other developing countries, however, he also held the states of the developed West responsible for the climate change, although for the future of the Philippines he takes the commitment seriously, which however will not be easy to be realized.

Serious environmental concerns have also arisen about the grandiose infrastructure investments despite the fact that Duterte asked the foreign corporations involved in the project to entirely comply with the requirements. The interpenetration of the corruption and the economic and social interests questions whether the Government can give an effective answer to the possible violations of law.

The closing of the tourism paradise of Boracay in April 2018 raised new questions concerning the compatibility of economic interests and environmental protection. Since the state failed to properly solve the issue of sewage supply and waste management on the island despite its promises, Duterte ordered the closing of the island for 6 months and the cleaning of the territory (Villamor, 2018). However, the absence of tourists not only jeopardizes the subsistence of the local population but can also cause a considerable loss of income for the Philippine economy. (In 2017 more than 2 million - mainly Chinese and South Korean - tourists visited the island of Boracay.)

\section{Conclusion}

After Rodrigo Duterte had been elected President, the Philippine Government recognized the serious ecological crisis situation and strongly committed towards the issue of environmental protection. At the same time, the Cabinet also prioritizes the economic and social development of the country, which, however, led to the conflict of interests even in the short term. In the past two years, President Duterte - although 
forced to pass numerous compromises - endeavoured to find a middle course and accelerate the development of the country in harmony with sustainable development. Today it cannot be clearly seen yet how successful his ambitions can be considered; nevertheless, the expectations are significant as compared to the challenge, and this raises several questions with respect to the future. Are environmental protection and industrialization compatible with each other? Will Duterte's reforms reach the desired aim? Can sustainable development be followed, or will economic interests ("lobby money speaks") dominate in the future, too? And finally, can the functioning ecosystems be preserved, or is the country approaching an ecological disaster?

These questions can only be answered by the future, but one thing is certain: each country of the global South faces a similar dilemma, so the model of the Philippines draws our attention to a problem that affects the future of all humanity last of all. Actually, in favour of development, environmental protection has no alternative because the following of short-term economic benefits can result in an irreversible ecological crisis, so it is a mutual interest to establish the appropriate balance. A great question is when the power elites will realize this and what actions they will be ready to take for the positive outcome.

\section{References}

Altez, J. A. and Caday, K. A. (2017). A Mindanaoan President. In: Curato, N. (ed) A Duterte Reader: Critical Essays on Rodrigo Duterte's Early Presidency. Cornell University Press, Ithaca, New York, pp 111-126.

Asian Development Bank (ADB), (2018). Poverty in the Philippines. Philippines. Available: https://www.adb.org/countries/philippines/poverty (accessed: April 23, 2018)

Batalla, V. C. (2018). Bypassing Industrial Development. In: Thompson M. R. and Batalla, V. C. (eds.): Routledge Handbook of the Contemporary Pbilippines. Routledge, New York.

Dela Cruz, E. (2018). UPDATE 1-Philippines says 23 of 27 mines pass review, but four may close. Reuters, August 2, 2018 Available: https://www.reuters.com/article/philippines-mining/update-1philippines-says-23-of-27-mines-pass-review-but-four-may-close-idUSL4N1UT21P (accessed: August 23, 2018)

Department of Environment and National Resources (DENR), (2017). Air Pollution: A Public Health Concern in the Philippines. September 24, 2017 Available: https://www.denr.gov.ph/news-andfeatures/latest-news/3295-air-pollution-a-public-health-concern-in-the-philippines.html (accessed: May 12, 2018)

Department of Environment and Natural Resources (DENR), (2018). Enhanced National Greening Program. Available: https://www.denr.gov.ph/priority-programs/national-greening-program.html (accessed: April 12, 2018)

Esty, D. and Ivanova M. H. (2004). Globalization and Environmental Protection: a Global Governance Perspective. Yale Center for Environmental Law \& Policy Working Paper Series, Working Paper 0402, $21 \quad$ July. Available: http://citeseerx.ist.psu.edu/viewdoc/download?doi=10.1.1.596.4578\&rep=rep1\&type=pdf

Focus Economics, (2018). Philippines Economy Data. Economic Forecasts from the World's Leading Economists. Available https://www.focus-economics.com/countries/philippines (accessed: April 23, 2018)

Jerusalem, J. J. (2016). Duterte: Green Energy is Good but We Need Coal. In: SunStar Philippines, December 10, 2016 Available: https://www.sunstar.com.ph/article/114723/ (accessed: April 12, 2018)

Lasco, R. D., Visco, R. G., Pulchin, J. M. (2001). Secondary Forests in the Philippines: Formation and Transformation in the 20th century. In: Journal of Tropical Forest Science, Vol, 13. No 4, 2001. pp. 652-670. 
Lucas, D. L. (2016). Energy Chief Gets Duterte's Green Light for \$1-B Nuke Plant Rehab. Inquirer.net, November 11, 2016 Available: http://business.inquirer.net/218869/energy-chief-gets-dutertesgreen-light-for-1-b-nuke-plant-rehab (accessed: April 22, 2017)

Manahan, M. A. (2017). Philippines Duterte's "schizophrenic" countryside and environmental agenda Laban-Bawi: Governing the Environment. In: Europe Solidaire Sans Frontières, 10 September 2017 Available: http://www.europe-solidaire.org/spip.php?article41966 (accessed: April 12, 2018)

Marrone, R. (2016). Water Pollution in the Philippines: Causes and Solutions. In: Borgen Magazine, October 2, 2016 Available: http://www.borgenmagazine.com/water-pollution-in-the-philippines/ (accessed: October 23, 2017)

Miller, J. (2018). Duterte Harry: Fire and Fury in the Philippines. Scribe, Melbourne-London.

National Economic and Development Authority (NEDA), (2017). Philippine Development Plan 2017-2022. Pasig City. Available: http://www.iro.ph/article doc/fc55bc53 PDP-2017-2022-Prepublication2.pdf (accessed: February 15, 2017)

Ngosso, T. (2013). The Right to Development of Developing Countries: An Argument against Environmental Protection? In: Public Reason, Vol 5, No 2, pp 3-20.

Palatino, M. (2018). Duterte Is Killing the Philippines' Environment. In: The Diplomat, August 27, 2018 Available: https://thediplomat.com/2018/08/duterte-is-killing-the-philippines-environment/ (accessed: August 29, 2018)

PCOO, (2017). DuterteNomics unveiled. Republic of the Philippines, Presidential Communications Operations Office, April 18, 2017 Available: https://pcoo.gov.ph/uncategorized/dutertenomicsunveiled/ (accessed: January 12, 2018)

Office of the President of the Philippines, Climate Change Commission (CCC), (2013). National Framework Strategy on Climate Change 2010-2022. December 15, 2013. Available: http://www.asialeds.org/sites/default/files/resource/file/nfscc sgd.pdf (accessed: April 12, 2018)

Philippine Commission on Women (PCW), (2018). Philippine Initiatives to Address Environmental Issues. National Machinery for Gender Equality and Women's Empowerment. Available: http://www.pcw.gov.ph/focus-areas/environment/climate-change/initiatives (accessed: April 12, 2018)

Plumer, B. (2017.). What to Expect as U.S. Leaves Paris Climate Accord. In: The New York Times, June 1, 2017 Available: https://www.nytimes.com/2017/06/01/climate/us-paris-accord-what-happensnext.html (accessed: January 12, 2018)

Ranada, P. (2018). Duterte Eyes Open-pit Mining Ban until 2019. Rappler, April 09, 2018 Available: https://www.rappler.com/nation/199876-duterte-open-pit-mining-ban-2019 (accessed: April 12, 2018)

Ranada, P. (2017). Duterte on CA votes vs Gina Lopez: 'Lobby money talks'. Rappler, May 04. Available: https://www.rappler.com/nation/168889-duterte-gina-lopez-lobby-money

Rappler, (2017). NDRRMC probes high death toll from tropical storm Vinta. December 25, 2017 Available: https://www.rappler.com/nation/192218-vinta-death-toll-evacuation-failure (accessed: January $15,2018)$

Office of the President of the Philippines, Climate Change Commission (CCC), (2013). National Framework Strategy on Climate Change 2010-2022. December 15, 2013. Available: http://www.asialeds.org/sites/default/files/resource/file/nfscc sgd.pdf (accessed: April 12, 2018)

Salaverria, L. B. (2017). Duterte Finally Signs Paris Agreement on Climate Change. Inquirer.net, March 02, 2017 Available: http://globalnation.inquirer.net/153030/duterte-finally-signs-paris-agrementclimate-change (accessed: April 22, 2017)

Santos, A. P. (2017). Philippines struggles to balance environment, mining. DW, May 17, 2017 Available https://www.dw.com/en/philippines-struggles-to-balance-environment-mining/a-38875328 (accessed: April 12, 2018)

Schneider, K. (2017). The Rise and Fall of Regina Lopez, the Philippines' Maverick Environment Minister. In: Mongabay, 9 May 2017 https://news.mongabay.com/2017/05/the-rise-and-fall-of-reginalopez-the-philippines-maverick-environment-minister/ (accessed: April 12, 2018) 
Tubayan, E. J. C. (2018). PHL to remain among SE Asia's fastest-growing economies - WB. In: Business World, January 11, 2018 Available: http://bworldonline.com/phl-remain-among-se-asias-fastestgrowing-economies-wb/ (accessed: April 23, 2018)

Update Philippines, (2016). Duterte admin adopts Ambisyon Natin 2040. Available: http://www.update.ph/2016/10/duterte-admin-adopts-ambisyon-natin-2040/10358 (accessed: February 15, 2017)

Villamor, F. (2018). Idyllic Philippine Resort Island of Boracay Is Closed to Tourists, In: The New York Times, April 4, 2018 Available: https://www.nytimes.com/2018/04/04/world/asia/boracay-philippinestourists-closed.html (accessed: May 12, 2018) 